\title{
Economic aspects of management and planning of waste processing system development
}

\author{
Edvard Tshovrebov', Evgeniy Velichko ${ }^{2, *}$, Ural Niyazgulov ${ }^{3}$, and Yuliya Sadchikova ${ }^{2}$ \\ ${ }^{1}$ Federal state autonomous institution "Research Institute" Center for environmental industrial policy", \\ Mytishchi, Moscow region, Russia \\ ${ }^{2}$ National Research Moscow State University of Civil Engineering (NRU MGSU), Moscow, Russia \\ ${ }^{3}$ Federal State Institution of Higher Education "Russian University of Transport", Moscow, Russia
}

\begin{abstract}
Annually, increasing volumes of industrial and municipal waste generation and disposal, leading to increasing anthropogenic environmental and sanitary-epidemiological pressure on the environment and, as a consequence, significant environmental damage and associated economic damage to natural ecosystems, represent one of the main threats to environmental safety territories, life and health of the population. At the same time, numerous valuable components extracted from processed production and consumption wastes can be an important source of reserve for the development of industries and sectors of the economy, entrepreneurial activities in the use of secondary resources for production, services, works and energy. This factor dictates the need to search for new sound management, economic, organizational and technical approaches and solutions to lawmaking, planning and forecasting the cost-effective organization of the system of separate collection, processing, disposal, disposal of production and consumption waste, the development of an appropriate industrial, scientific and technological infrastructure, increasing the share of secondary material and energy resources extracted from waste, the development of instruments of state oh support and economic incentives for this activity.
\end{abstract}

\section{Introduction}

In the course of the history of the development of the Soviet state, modern Russia, attempts to solve the urgent problem of waste management in a complex and effective way for the country's economy arose in the process of creating various strategies, concepts, and programs. Over the years, were formed: The concept of solid waste management (GU "NITSPURO, 2000); The concept of development of the waste management industry for 2013-2024; the project "Development of a model for the implementation of complex projects in the field of solid waste management on the example of the Central Federal District (2014); the project "Development of a program for the development of the industry and technologies for the recycling of industrial waste and the housing and public utilities complex" (SOPS FNBIU, 2015); The program of formation of the industry of waste

\footnotetext{
* Corresponding author: pct44@yandex.ru
} 
management of production and consumption; The concept of "Regional Center for the treatment of industrial waste" and a number of other works. However, it was not possible to bring any of them to practical implementation within the framework of creating an integrated system for processing, recycling, and neutralizing waste with the issuance of a regulatory legal act of the federal level. Moreover, until recently, there were no effective steps in our country to form and economically justify an integrated system of handling both industrial and municipal waste, which could be regulated at the legislative level.

The extreme urgency and significance of the problem predetermined the widespread use in the course of the research conducted on the basis of the Scientific Research Institute "Center for Environmental Industrial Policy" of scientific and methodological developments of domestic authors [1-5], materials of analysis of international experience in the field of waste management, using regulatory legal and economic instruments in this area [6-15], regulatory documents of strategic planning of various sectors of the economy, scientific research, authors' works in the field of economic and environmental aspects of waste management and [16-22] in the process of participating in the creation of sectoral strategic planning document - Strategies for the development of industry in the treatment, disposal and disposal of industrial and consumption waste for the period up to 2030, approved in January 2018 HAND Russian Federation.

The analysis of the studied problem showed the relevance and urgent need for the creation and development at the present stage of development of society of an integrated system of waste management and the use of secondary resources as a reserve for the socioeconomic development of the country.

\section{Materials and Methods}

The aim of the research was the development of methodological foundations, as well as scientific and methodological substantiation of legal regulation, organizational and managerial, economic principles of location, long-term planning, forecasting of industrial infrastructure for processing, recycling, waste disposal, economic system of secondary resources.

The object of scientific research in the field of creating a cost-effective system for planning and forecasting the development of waste-processing infrastructure for the future is a management system that belongs to the class of socio-economic systems and is being formed within all types of public relations.

Materials for conducting a scientific research are: legislative base, legal acts, standards, guidelines, design and regulatory and technical documentation in the field of waste management, published data and materials of domestic and foreign scientific research on this topic.

The methods of scientific research are based on the use of factor and comparative analysis, the theory of constraints, and expert methods for evaluating indicators.

In conducting the study, the hypothesis was adopted and then analyzed that a systematic integrated approach to the study of the activity of the research object — the production and economic system for managing the waste-processing infrastructure and the waste management system as a whole, identifying and evaluating the contradictory influence on it of individual factors related to intersubject and interdepartmental interaction, generalization of the analysis materials in the form of conclusions and recommendations based on processing by special techniques in This available information on the performance of such a management system, as well as the rationale for the effectiveness of management decisions, should be carried out by an analysis method that includes studying the subject by dividing it into its constituent elements (parts of the object, signs, properties, characteristics, parameters) and analyzing each of the parts separately within a single whole. 


\section{Results}

The methods, tools and approaches used by the authors have made it possible to comprehensively and optimally approach the resolution of the main problem in achieving the completeness, validity, and dynamic prediction of technical and economic indicators of forming the waste-processing industry for the future, creating scenarios for its development and strategic directions.

In the course of scientific research, it was taken into account that the successful effective development of the industry for the treatment, disposal and disposal of waste depends on the creation and operation of a strategically oriented, targeted, integrated, balanced, integrated with the sectors (sectors) economy system in the country. stages of waste management, ranging from their separate collection, processing and ending with the production and sale of high-quality, environmentally safe competitive products from recycled materials, as well as domestic high-tech equipment, equipment, installations, innovative technologies in the Russian and international markets.

As the main mechanism for the formation of the aforesaid management system, the following main provisions are defined:

- creation of an effective regulatory and legal framework in the field of energy and resource conservation, as well as domestic standards of products from recycled materials, not inferior to their counterparts in the leading countries of the world;

- a complete ban on the disposal of secondary raw materials in the country, as well as waste, which are sources of valuable secondary resources (useful components) from them; - the introduction of the collateral value for certain types of waste consumption in order to ensure the maximum level of their collection (first of all, extremely and highly hazardous, as well as being in-demand secondary raw materials); the introduction of mandatory standards for the maintenance of waste in products: construction, furniture, electronic and electrical, as well as in the cost of providing services for heating, hot water, sewage, etc .; - optimal functioning of the system of extended responsibility of manufacturers as the responsibility of manufacturers themselves to organize collection systems, utilization of obsolete products;

- introduction in the regions of effective integrated management systems, accounting, regulation, control of waste management and secondary resources;

- optimization and concentration of the disparate infrastructure of potential and existing waste treatment plants as part of large investment programs for innovative consolidation of uncompetitive companies, concentration and increase of production efficiency;

- optimal scientifically-practically-based planning and forecasting for the future of processing infrastructure (waste sorting complexes and transfer stations), recycling (creation of new enterprises, as well as industries, sites, workshops at existing facilities for the production of secondary raw materials), neutralization (high-temperature calcination , plasma gasification, pyrolysis, neutralization) of production and consumption waste;

- the creation and expansion of the domestic competitive machine-building base for the production of equipment, machinery, equipment to ensure the effective uninterrupted functioning of the waste-processing infrastructure,

- development of scientific and technical base by consolidating the development and training of specialists of research and educational institutions, industrial associations, enterprises on the platform of scientific and industrial clusters, environmental technology parks, the creation of innovative best available technologies in this field;

- formation of an integrated system of separate collection and pre-processing, taken from the population and enterprises of secondary resources, financial and economic interest of individuals and legal entities in this process with the creation of a network of stationary and mobile collection points for secondary raw materials; 
- provision by the state, along with the tax and complex of other types of economic incentives (benefits, preferences, differentiation of payments, fees), support to private investors in creating research and production clusters in the field of waste treatment and disposal, production of recycled materials, domestic equipment with the use of innovative technologies in the format of territorial and sectoral specifics;

- coordinated initiatives of the authorities and development institutions for the formation of sustainable demand for products from secondary raw materials, including the introduction of mandatory procurement for state orders (regional, municipal) for certain types of goods produced using waste;

- tightly controlled by the government and the public targets for the formation and development of the waste-processing industry (Table 1).

Table 1. The main targets of waste industry.

\begin{tabular}{|c|c|}
\hline Name of the target & $\begin{array}{l}\text { Units } \\
\text { measure }\end{array}$ \\
\hline $\begin{array}{c}\text { The proportion of recycled and neutralized waste in the total waste } \\
\text { generated }\end{array}$ & $\%$ \\
\hline $\begin{array}{l}\text { Ratio waste directed to the processing of the total volume removed } \\
\text { from the storage places }\end{array}$ & $\%$ \\
\hline Number of created environmental technology parks & $\mathrm{u}$ \\
\hline $\begin{array}{c}\text { Number of established production-technical complexes processing } \\
\text { waste (production of product recycled) }\end{array}$ & $\mathrm{u}$ \\
\hline $\begin{array}{l}\begin{array}{l}\text { Number of created multifunctional complexes for industrial waste } \\
\text { disposal }\end{array} \\
\end{array}$ & $\mathrm{u}$ \\
\hline The amount of multifunctional sorting systems & $\mathrm{u}$ \\
\hline $\begin{array}{c}\text { Level of localization of production of equipment for processing, } \\
\text { utilization and neutralization of waste }\end{array}$ & $\%$ \\
\hline $\begin{array}{l}\text { Contribution of the waste treatment, utilization and disposal industry to } \\
\text { the gross domestic product (GDP) of the country }\end{array}$ & $\%$ \\
\hline Level of waste reduction & $\%$ \\
\hline $\begin{array}{l}\text { Share of imports of equipment for processing, utilization and disposal } \\
\text { of production and consumption wastes }\end{array}$ & $\%$ \\
\hline $\begin{array}{l}\text { Resource potential for certain types of waste (replacement of non- } \\
\text { renewable natural resources (forest, water, minerals) - secondary } \\
\text { resources from waste) }\end{array}$ & $\%$, tonne \\
\hline
\end{tabular}

\section{Discussion}

According to the results of the research, the problem of their successful testing within the framework of the creation of Federal and regional systems for waste and secondary resources management comes to the fore.

This innovative system is expected to pass a broad discussion and to obtain a multidimensional assessment at all levels of government and broad strata of Russian society: the inhabitants of the country, expert, scientific, business community, public 
associations, mass media. For example, it was found that the greatest excitement among the citizens of the country is the idea of incineration of unsorted waste, universally rejected by citizens on the results of public hearings. The degree of danger to the health of the population and future generations of the operation of such facilities in Russia is poorly understood and cannot but cause fair fears. The majority of the population does not understand where and what the funds collected from them in the form of payments for the export and disposal of solid municipal and large-size waste are going and why, as a result of the implementation of the "garbage" reform, the situation with the clutter of waste areas does not change in some regions for the better?

The basic principle of the above-mentioned scientific and methodological approach is to provide citizens, the business community with the right and opportunities to choose the form of personal organizational and financial participation in solving the problem of waste management in our country. According to the authors, formed by results of research organizational-economic and administrative-regulatory framework and principles of a complex system of separate collection and treatment of waste in the settlements and economic entities with the most technically feasible, environmentally acceptable and economically feasible the extraction of valuable secondary resources, as well as state support and economic incentives the markets for such raw materials, production, energy recovery from it, could be a conceptual direction of the reform on waste management.

At the same time, awareness of the General population, environmental education, training and education in the field of activities at various stages of waste management and secondary resources will contribute to the improvement of the overall level of environmental culture.

\section{Conclusions}

The results obtained in their implementation by Federal and regional authorities, regional operators of waste management, in industrial production, as well as in the system of intersectoral, interdepartmental and inter-subject interaction will allow to achieve:

- the economic effect connected with increase in quantity and cost of the allocated secondary resources brought to the level of secondary raw materials, the profitable component from realization directly secondary raw materials (scrap metal, waste paper, etc.), and also production, services, works, energy with use of secondary resources;

- environmental effect caused by a significant reduction in the receipt of non-utilised municipal waste for landfill disposal, reduction in the cost of waste treatment, reduction of economic and environmental damage to environmental components;

- the natural resource effect determined by economy of non-renewable natural resources in production processes as a result of replacement by the secondary, allocated from industrial and municipal waste;

- socio-economic impact caused by the reduction of tariffs for the population for the removal and disposal of garbage, as well as awareness of citizens of the need for separate collection of these waste materials, their processing, maximize the use for their own household needs, effective economic stimulation of these processes, reduction of morbidity, formation of new workplaces at the enterprises waste processing infrastructure, the emergence of new high-quality environmentally friendly, safe products, manufactured using recycled materials;

- organizational and managerial effect associated with the establishment of a full-fledged objective system of management, regulation, accounting, monitoring of circulation, secondary material resources; 
- the political effect associated with the reduction of tension in society because of the unsolvable "garbage problem", the threat of environmental danger, the growth of tariffs for the population in the housing and communal services system.

The concept of planning and forecasting of waste processing system proposed by the authors can be used in the development and updating of regional concepts, strategies, programs, territorial schemes for waste management, in the process of business planning, at the pre-project and project stages of the formation of infrastructure for processing, recycling, waste disposal.

The scientific and practical results of the research have already been implemented in the development of a Strategy for the treatment, utilization, disposal of production and consumption waste for the period up to 2030, the forecast of development of the waste processing industry for the long, medium and short term, planning a set of measures for the implementation of this Strategy.

\section{References}

1. E. Tshovrebov, S.V. Sadova, Bull. of the Ac. of Nat. Scien. 2, 57 (2014)

2. M.Ya. Bikbau, Env. Syst. and Dev. 7, 26 (2018)

3. G.S. Nikitin, V.S. Osmakov, D.O. Skobelev, Comp. 3, 29 (2017)

4. E.G. Velichko, E. Tshovrebov, A.E. Mednov Hous. Const. 8, 48 (2014)

5. E. Tshovrebov, Bul. of Kost. St. Un. N. Ah. Nekrasov 3, 10 (2013)

6. R. Murray, Zero waste. Greenpeace environmental trust. (2002)

7. F.C. Mihai, Dim. Cant. 33, 39 (2012)

8. G. Mothi, Urban solid waste management: a micro analysis (The University of Kerala, Thiruvananthapuram, 2012)

9. M. Mazzanti, R. Zoboli, Res., Cons. and Rec. 25, 1221 (2008)

10. K. Abeliotis, Int. Was. Man. 1, 24 (2011)

11. N. Ai, The concept of solid waste management (Georgia Institute of Technology, Atlanta, 2011)

12. W. Sornil, J. of Sol. Was. Tech. and Man. 40, 33 (2014)

13. D. Marković, Fact. Univers.: Mech. Eng. 8, 65 (2008)

14. M. Hauschild, Sol. Was. Techn. and Man. 1, 113 (2011)

15. G. De Feo, Was. Man. 34, (2014)

16. K. Berninger Conf. Present. 4 (2010)

17. S. Dimitris, D.S. Achilias, InTech, 406 (2012)

18. J.D. Nixon, D.G. Wright, P.K. Dey, S.K. Ghosh, P.A. Davies, Waste Man. 33, 2234 (2012)

19. P. Aragones-Beltrana, J.P. Pastor-Ferrandoa, F. Garca-Garca, A. Pascual-Agullo, Jour. of Env. Man. 91, 1071 (2010)

20. P. Belli, J.R. Anderson, H.N. Barnum, J.A. Dixon, J.P. Tan, The Int. Bank for Rec. and Dev. 46 (2001)

21. N. Celik, E. Antmann, X. Shi, B. Hayton, Dep. of Ind. Eng. Univ. of Miami 34 (2012)

22. I. Ilin, O.V. Kalinina, O. Iliashenko, A. Levina, Procedia Engineering, 165, 1673-1682. (2016) doi: 10.1016/j.proeng.2016.11.909 